\title{
Faktor - faktor yang mempengaruhi wisatawan dalam pemilihan akomodasi di kabupaten jembrana
}

\author{
Ni Putu Krisnadevi ${ }^{1)}$, Anak Agung Putri Sri ${ }^{2)}$, Agus Muriawan Putra ${ }^{3)}$ \\ Program Studi Diploma IV Pariwisa ta, Fakultas Pariwisa ta, Universitas Udayana ${ }^{1 \text { ) }}{ }^{2}$ ) \\ Jl. Dr. R. Goris No.7, Dangin Puri Klod, Denpasar Tim.,Kota Denpasar ${ }^{1)}$ ) 3) \\ krisnadevi1212@gmail.com ${ }^{1)}$
}

\begin{abstract}
Abstrak
Akomodasi wisa ta merupakan salah sa tu penunjang kgia tan pariwisata di Ka bupaten Jembrana. Na mun terdapatbanyak akomodasi yang mengalami kegagalan dalam beroprasi oleh karena sedikitn ya jumlah kunjungan wisa tawan yang datang. Tujuan Penelitian ini un tuk m en getahui faktor-faktor yang mempengaruhi wisatawan dalam pemilihan akomodasi di Kabupaten Jembrana dan fakt or y ang dominan mempengaruhi wisa tawan dalam pemilihan akomodasi di Kabupaten Jembrana sehingga nantin ya d apat digunakan sebagai masukan bagi penyedia akomodasi dalam pengelolaan akomodasi wis a ta y ang a da di Kabupaten Jembrana.

Teknik pengumpulan data menggunakan metode observasi, kuesioner, dokumentasi, studi kepustakaan dan analisis da ta meggunakan teknik a nalisis deskriptif kualitatif dengan uji va liditas, uji reliabilita dan analisis faktor y ang dibantu dengan program SPSS versi 22.

Ha sil penelitian menunjukan bahwa berdasarkan ujivaliditas dan uji reliabilitas pada 21 in dikator penelitian dengan menggunakan program SPSS versi 22 semua variabel din y atakan valid dan reliable, sehingga 21 indikator tersebut dapat dilanjutkan pada tahap selanjutnya yaitu analisis fa ktor. B erdasarka $n$ hasil a nalisis faktor didapat 4 faktor yang terdiri dari 14 indikator yang mempen garu hi wisa ta wan dala m pemiliha nakomodasi wisa ta di Ka bupaten Jembrana. Empatf akt or y ang terbent uk terdiri da ri Fa kt or Kualitas Pelayanan, Faktor Reputasi, Faktor Lokasi dan Faktor Harga. Faktor yang dominan mempenga ruhi wisa ta wan dalam pemilihan akomodasi di Kabupaten Jembrana adalah Faktor Ku alitas Pela yanan yang terbentuk a tas 4 indikator yaitu pemilihan akomodasi ka renakemampuan staff melakukan komunika si y ang baik, pemilihan akomodasi karena kelengkapan fasilita s kamar, pemilihan a komodasi b erd a sarkan de sign bangunan akomodasi, pemilihan akomodasi berdasarkan referensi teman atau kolega.
\end{abstract}

Kata Kunci: Ana lisis Faktor, Pemilihan Akomodasi Wisata, Wisa tawan

\section{Abstract}

Tourist accommodation is one of the supporting activities of tourism in Jembrana Regency. However, there are many a ccommodations that fail to operate due to the small number of tourist a rrivals. The purpose of this study is to determine the factors that influence tourists choosing a ccommodation in Jembrana Regency and the dominant factors affecting tourists in choosing accommodation in Jembrana Regency so it can use a s input for accommodation providers to manage tourist a ccommodation in Jemb rana Regency. Methods of collecting data are through observation, questionaire, documentation and literature study method. Method for da ta analysis a re use descriptive qualitative method through validity test, relia bility test, a nd a naly sis factor u sing SPSS progra m version 22 .

The result of the study show that a ccording to validity and reliability test doneby SPSS version 22 all 21 indica tors are valid and reliable that mean it can becontinued to factor a nalysis. Based on the results of factor analysis, there are 4 factors consisting of 14 indicators that influence tourists in the selection of tourist a ccommodation in Jembrana Regency such as Service Quality Fa ctors, Reputation Factors, Location Factors and Price Factors. The dominant factor influencing tourists in choosing accommodation in Jembra na Regency is the Service Quality Factor which is formed on 4 indicators, such as choosing accommodation due to the ability of staff to communicate well, choosing accommodation due to the completeness of room facilities, choosing accommodation based on the design of the accommodation building, choosing a ccommodation based on a friend or colleague's reference.

Keywords: Factors Analisy s, Choosing Accomodation, Tourist

\section{PENDAHULUAN}

Bali merupakan pulau yang terkenal akan pariwisatanya. Secara geografis Bali terletak di bagian tengah dari wilayah Indonesia yang berbatasan langsung dengan Pulau Jawa dan Pulau Lombok. Pulau Bali yang terdiri dari delapan kabupaten dan satu kota madya ini kerap menjadi daya tarik wisata favorit bagi wisatawan mancanegara maupun wisatawan nusantara. Bali juga dikenal dengan berbagai julukan yaitu mulai dari The Island of Paradise karena keindahan alam 
maupun budaya yang terdapat di Bali, selain itu Bali juga mendapat julukan The Island Of Thousand Tamples dikarenakan mayoritas penduduk Bali merupakan pemeluk agama hindu yang memberikan keunikan tersendiri baginya.

Berbagai keunikan yang ada di Bali semakin menarik keinginan wisatawan mancanegara maupun wisatawan nusantara untuk berkunjung ke Bali. Bukan hanya wisata budaya yang tersedia di Bali. Banyak pula wisata alam maupun wisata lainnya yang mampu menarik minat wisatawan untuk menjadikan Bali sebagai tujuan utama untuk berwisata. Hal tersebut dapat dilihat dari meningkatnya kunjungan wisatawan yang datang ke Bali. Terhitung pada tahun 2016 rata-rata jumlah wisatawan yang datang ke Bali menurut Badan Pusat Statistik Provinsi Bali mencapai 11 juta wisatawan yang terdiri dari wisatawan nusantara dan mancanegara. Adapun data jumlah kunjungan wisatawan nusantara maupun mancanegara yang berkunjung ke Bali tahun 2013 sampai dengan tahun 2018 dapat dilihat pada Tabel 1.1 berikut.

Tabel 1. Jum lah Kunjungan Wisatawan Mancanegara dan Wisa tawan Nusantara

ke Bali Tahun 2013-2018

\begin{tabular}{|c|c|c|c|c|}
\hline \multirow[t]{2}{*}{ Tahun } & \multicolumn{2}{|c|}{ Jumlah Wisatawan(Orang) } & Tota1Jumlah & Pertumbuhan \\
\hline & Mancanegara & Nusantara & $\begin{array}{c}\text { Wisatawan } \\
\text { (Orang) }\end{array}$ & $(\%)$ \\
\hline 2013 & 2.892 .019 & 6.063 .558 & 8.955 .577 & - \\
\hline 2014 & 3.278 .598 & 6.976 .536 & 10.255 .134 & 14,51 \\
\hline 2015 & 3.766 .638 & 6.392 .460 & 10.159 .098 & $-0,94$ \\
\hline 2016 & 4.001 .833 & 7.147 .100 & 11.487 .935 & 9,74 \\
\hline 2017 & 4.927 .937 & 8.643 .680 & 13.572 .617 & 21,74 \\
\hline 2018 & 5.697 .739 & 9.135 .740 & 14.833 .479 & 9,29 \\
\hline Total & 24.564 .766 & 44.359 .074 & 68.924 .840 & 54,35 \\
\hline Rata-Rata & 4.094 .127 & 7.393 .179 & 11.487 .473 & 10,87 \\
\hline
\end{tabular}

Sumber: Dinas Pariwisata Provinsi Bali, 2019

Bedasarkan tabel 1 dapat dilihat bahwa pertumbuhan wisatawan yang datang ke Bali dari tahun 2013 sampai tahun 2018 mengalami peningkatan. Pada tahun 2013 terdapat 8.955.557 wisatawan yang datang ke Bali dan mengalami peningkatan sejumlah 14,5 persen, walaupun pada tahun 2015 terdapat penurunan sebesar 0,95 persen dari tahun 2013, jumlah kunjungan wisataw an kembali meningkat yaitu pada tahun 2016 dimana peningkatannya mencapai 9,73 persen. Pada tahun 2017 terdapat kunjungan wisatawan sebanyak 13.572.167 wisatawan, yang berarti pada tahun 2017 terjadi peningkatan tertinggi sebanyak 21,7 persen jumlah wisatawan dari tahun sebelumnya. Sedangkan pada tahun 2018 jumlah wisatawan yang berkunjung ke Bali adalah 14.833.479 dengan peningkatan sebesar 9,29 dibandingkan tahun sebelumnya.

Penurunan jumlah kunjungan wisatawan terjadi pada tahun 2015, hal ini disebabkan oleh berbagai isu yang terjadi di dunia yang menyebabkan menurunnya minat berwisata. Banyaknya aksi terorisme yang terjadi di tahun 2015 juga menyebabkan banyak wisatawan mengurungkan niatnya untuk berwisata. Sedangkan peningkatan tertinggi jumlah kunjungan wisatawan ke Bali terjadi di tahun 2017. Hal ini dikarenakan pada tahun 2017 dilasanakan berbagai macam promosi yang dilakukan oleh pemerintah untuk mencapai target kunjungan wisatawan tahun 2018. Salah satu hal yang dilakukan adalah dengan menciptakan berbagai destinasi wisata baru yang ada di bali. Dari data di atas dapat disimpulkan bahwa dalam kurun waktu 5 tahun terus terjadi peningkatan pada kunjungan wisatawan ke Bali, baik wisatawan nusantara maupun mancanegara. Namun dengan peningkatan jumlah kunjungan wisatawan ke Bali tidak semata-mata seluruh kunjungan wisatawan di masing-masing kabupaten mengalami peningkatan pula. Salah satu kabupaten di Bali yang mengembangkan pariwisata namun belum mendapat peningkatan kunjungan adalah Kabupaten Jembrana.

Kabupaten Jembrana merupakan salah satu kabupaten yang terletak di bagian barat Pulau Bali. Untuk mencapai Kabupaten Jembrana memakan waktu kurang lebih 3 jam ditempuh dari Bandara Internasional Ngurah Rai atau sekitar 30 menit perjalanan dari Pelabuhan Gilimanuk. Perkembangan pariwisata di Kabupaten Jembrana memang tidak sepesat kabupaten lain seperti 
Kabupaten Badung, Tabanan maupun Gianyar. Namun di Kabupaten Jembrana juga terdapat berbagai daya tarik wisata yang cukup terkenal seperti Pura Rambut Siwi, Pantai Medewi, Wisata Bunut Bolong, Pantai Cadiksuma, serta Taman Nasional Bali Barat. Selain itu lokasi Kabupaten Jembrana yang berada di ujung barat Pulau Bali, menjadikan Kabupaten Jembrana sebagai pintu gerbang penghubung antara Pulau Bali dengan Pulau jawa. Namun dengan adanya hal tersebut, belum mampu menarik banyak wisatawan untuk datang berkunjung ke Kabupaten Jembrana. Adapun data jumlah kunjungan wisatawan ke Kabupaten Jembrana dapat dilihat pada tabel 1.2 berikut.

Tabel2. Da ta Jumlah Kunjungan Wisatawan Kabupaten Jembrana Tahun 2018

\begin{tabular}{cccccc}
\hline NO & Bulan & $\begin{array}{c}\text { Wisatawan } \\
\text { Mancanegara }\end{array}$ & $\begin{array}{c}\text { Wisatawan } \\
\text { Nusantara }\end{array}$ & Jumlah & Pertumbuhan (\%) \\
\hline 1 & Januari & 1.181 & 28.105 & 29.286 & 0 \\
2 & Februari & 996 & 19.269 & 20.265 & $-0,308$ \\
3 & Maret & 967 & 19.949 & 20.916 & 0,032 \\
4 & April & 1.343 & 17.662 & 19.005 & $-0,091$ \\
5 & Mei & 1.462 & 20.525 & 21.987 & 0,157 \\
6 & Juni & 1.496 & 27.327 & 28.823 & 0,311 \\
7 & Juli & 2.453 & 28.454 & 30.907 & 0,072 \\
8 & Agustus & 4.997 & 18.190 & 23.187 & $-0,250$ \\
9 & September & 2.758 & 17.524 & 20.282 & $-0,125$ \\
10 & Oktober & 4.894 & 13.904 & 18.798 & $-0,073$ \\
11 & November & 1.571 & 14.916 & 16.487 & $-0,123$ \\
12 & Desember & 967 & 9.599 & 10.566 & $-0,359$ \\
& Jumlah & 25.007 & 235.424 & 260.431 & \\
\hline
\end{tabular}

Sumber: Dinas Pariwisata Kabupaten Jembrana. 2019

Pada tabel 2 di atas dapat dilihat bahwa kunjungan wisatawan ke Kabupaten Jembrana pada tahun 2018 mencapai jumlah 260.431 kunjungan yang terdiri dari 25.007 wisatawan mancanegara dan 235.424 wisatawan nusantara. Dapat dilihat bahwa wisatawan yang dominan berkunjung ke Kabupaten Jembrana adalah wisawan nusantara, terbukti dari jumlah kunjungan wisatawan nusantara yang lebih besar dibandingkan wisatawan mancanegara. Pada tahun 2018, kunjungan wiatawan ke Kabupaten Jembrana cenderung mengalami penurunan tiap bulannya. Dengan kecilnya jumlah kunjungan wisatawan ke Kabupaten Jembrana, berimbas pula pada pelaku usaha wisata di Kabupaten Jembrana.

Apabila dilihat berdasarkan konsep 4A dalam pengembangan pariwisata, akomodasi merupakan salah satu unsur pendukung dari perkembangan pariwisata yaitu pada bidang Amenities. Sejalan dengan berkembangnya pariwisata di Kabupaten Jembrana, telah berkembang pula berbagai akomodasi wisata sebagai penunjang adanya pariwisata di Kabupaten Jembrana. Akomodasi wisata yang ada di Kabupaten Jembrana tersebar disetiap kecamatan, dengan pilihan harga dan fasilitas yang bermacam-macam. Adapun jumlah akomodasi wisata yang beroperasi di Kabupaten Jembrana dapat dilihat pada tabel 3 berikut.

Tabel3. Data Jumlah Akomodasi Wisata di Kabupaten Jembrana tahun 2018

\begin{tabular}{ccccc}
\hline No & Kecamatan & $\begin{array}{c}\text { Hotel } \\
\text { (Unit) }\end{array}$ & $\begin{array}{c}\text { Pondok Wisata } \\
\text { (Unit) }\end{array}$ & $\begin{array}{c}\text { Jumlah } \\
\text { (Unit) }\end{array}$ \\
\hline 1 & Pekutatan & 13 & 18 & 31 \\
2 & Mendoyo & 8 & 8 & 16 \\
3 & Jembrana & 11 & 13 & 24 \\
4 & Negara & 19 & 4 & 23 \\
5 & Melaya & 15 & 8 & 23 \\
\hline
\end{tabular}




\begin{tabular}{cc}
\hline Total & 117 \\
\hline Sumber: Dinas Pariwisata Kabupaten Jembrana, 2019
\end{tabular}

Dari Tabel 3 di atas dapat dilihat bahwa jumlah akomodasi wisata di Kabupaten Jembrana yaitu 117 unit, yang tersebar pada lima kecamatan yaitu Kecamatan Pekutatan, Kecamatan Mendoyo, Kecamatan Jembrana, Kecamatan Negara dan Kecamatan Melaya. Di Kecamatan Pekutatan terdapat sejumlah 31 unit akomodasi wisata, sedangkan di Kecamatan Mendoyo terdapat 16 unit dan Kecamatan Jembrana terdapat 24 unit akomodasi wisata. Sedangkan di Kecamatan Negara dan Melaya terdapat 23 unit akomodasi. Jika dilihat dari Tabel 3 di atas, kecamatan dengan jumlah akomodasi terbanyak di Kabupaten Jembrana adalah Kecamatan Pekutatan. Adapun dari 117 unit akomodasi yang ada di Kabupaten Jembrana, terdapat beberapa akomodasi yang memiliki popularitas tertinggi di masing-masing kecamatan berdasarkan banyaknya ulasan yang ada pada trip advisor. Berikut merupakan data akomodasi terpopuler di masing-masing kecamatan di Kabupaten Jembrana berdasarkan situs Trip Advisor dapat dilihat pada Tabel 4 dibawah ini.

Tabel4. Daftar 10 Akomodasi Wisata Populerdi Kabupaten JembranaBerdasarkan Trip Advisor Tahun 2019

\begin{tabular}{rlcr}
\hline No & \multicolumn{1}{c}{ Nama Akomodasi } & Lokasi & Jumlah Ula san \\
\hline 1 & Puri Dajuma BeachEco and Resort & Pekutatan & 503 \\
2 & Kelapa Retreat and Spa & Pekutatan & 324 \\
3 & Anara Surfing camp & Mendoyo & 176 \\
4 & BaliTiger Hideway & Mendoyo & 174 \\
5 & Hardy's Hotel & Jembrana & 407 \\
6 & Segara Mandala Hotel & Jembrana & 115 \\
7 & Jimbarwana Hotel & Negara & 306 \\
8 & BaliSunset Hotel Jembrana & Negara & 54 \\
9 & The Arya Gilimanuk & Melaya & 107 \\
10 & Taman Wana Resort Palasari & Melaya & 96 \\
\hline
\end{tabular}

Sumber: Hasil Penelitian, 2019

Berdasarkan tabel 4 di atas dapat dilihat bahwa dari 10 akomodasi yang popular berdasarkan ulasan wisatawan di Kabupaten Jembrana tahun 2019, Puri Dajuma Beach Eco and Resort memiliki ulasan terbanyak yaitu sebanyak 503 ulasan. Sedangkan akomodasi yang memiliki ulasan yang paling sedikit adalah Bali Sunset Hotel Jembrana yang terletak di Kecamatan Negara yaitu dengan 54 ulasan. Jika dibandingkan dengan jumlah kunjungan wisatawan yang datang ke Kabupaten Jembrana, jumlah akomodasi wisata yang ada di Kabupaten Jembrana terbilang cukup banyak. Hal ini menyebabkan adanya persaingan antara akomodasi-akomodasi yang ada dalam hal penjualan kamar. Tidak hanya itu persaingan juga terdapat pada fasilitas dan harga kamar yang cenderung rendah, sehingga dapat menyebabkan kerugian pada akomodasi wisata tersebut. Akibatnya banyak akomodasi wisata di Kabupaten Jembrana yang terbengkalai dan bangkrut karena tidak lakunya kamar yang ditawarkan. Salah satu akomodasi yang terbengkalai di Kabupaten Jembrana terdapat di Kecamatan Pekutatan yaitu di Desa Pengeragoan. Adapun akomodasi tersebut dapat dilihat pada gambar 1.1 berikut. 


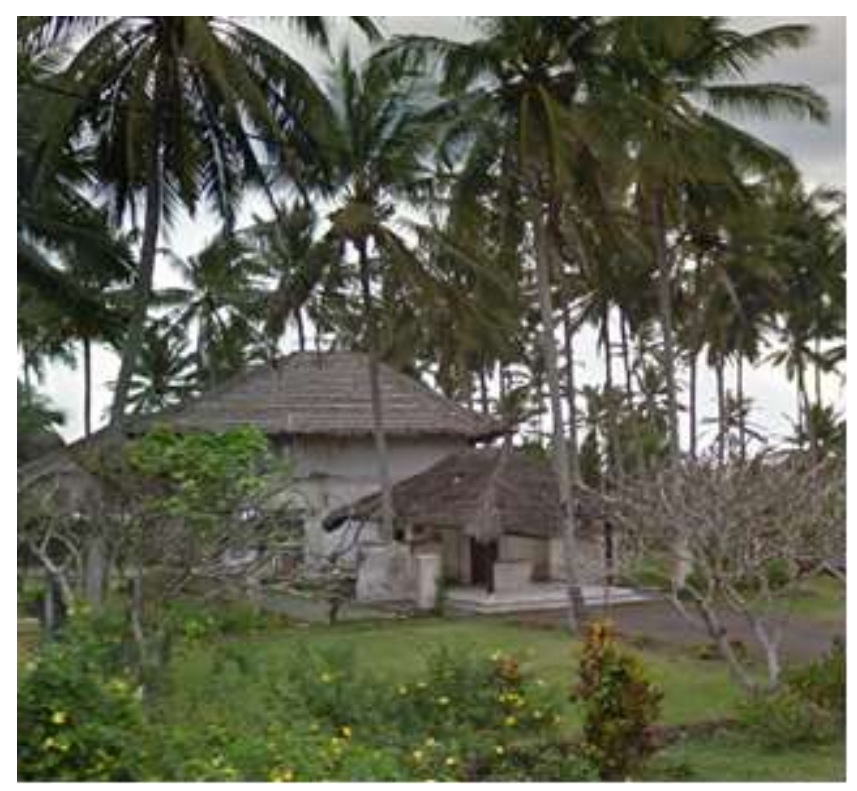

Gambar 1. Akomodasi Rusak di Kabupaten Jembrana Sumber: Dokumentasi, 2019

Pada gambar 1 di atas dapat dilihat bahwa kondisi akomodasi wisata yang tidak terurus, baik bangunan dan atap yang sudah roboh. Adapun lokasi akomodasi tersebut berada di Jalan Raya Denpasar-gilimanuk yang merupakan jalan utama yang digunakan sebagai jalur mobilisasi dari Pelabuhan Gilimanuk menuju Pusat Kota Denpasar maupun kota lainnya. Hal ini menunjukan bahwa akomodasi tersebut dapat diakses dengan mudah menggunakan kendaraan roda dua maupun roda empat. Selain itu lokasi akomodasi wisata pada gambar 1.1 di atas Pantai Pengeragoan dan Pantai Medewi. Namun pada kenyataanya lokasi tersebut belum mampu menarik minat wisataw an untuk menginap di akomodasi tersebut, sehingga pada akhirnya tidak dapat bertahan dan bangkrut. Namun walaupun terdapat beberapa akomodasi wisata yang bangkrut dan terbengkalai, usaha akomodasi wisata di Kabupaten Jembrana masih dapat berjalan, terbukti dengan adanya akomodasi yang masih beroperasi sampai saat ini.

Melalui beberapa strategi pemasaran yang dilakukan, tentunya akan dapat menarik minat wisatawan untuk menginap di akomodasi wisata di Kabupaten Jembrana. Dalam menentukan pilihan akomodasi oleh wisatawan, tentunya akan terdapat berbagai pertimbangan sebelum akhirnya memutuskan untuk menginap di suatu akomodasi. Adapun keinginan wisatawan akan berbeda antara wisatawan satu dengan wisatawan lainnya. Oleh karena itu penyedia akomodasi harus mampu memenuhi keinginan dan kebutuhan wisatawan guna meningkatkan kepuasan wisatawan yang nantinya akan mampu menarik minat wisatawan untuk menginap.

Mengetahui keinginan wisatan terhadap keputusan memilih akomodasi sangatlah penting bagi penyedia jasa akomodasi. Hal tersebut nantinya akan mampu memberikan keuntungan bagi pemilik akomodasi wisata untuk mempersiapkan akomodasi yang sesuai dengan keinginan wisatawan mengingat akomodasi wisata merupan salah satu unsur penting yang digunakan dalam menunjang pengembangan dan kegiatan kepariwisataan. Oleh karena itu, dirasa perlu diadakan penelitian tentang "Faktor-faktor yang mempengaruhi wisatawan dalam memilih akomodasi di Kabupaten Jembrana" untuk mengetahui bagaimana wisatawan dalam memilih akomodasi di Kabupaten Jembrana.

\section{METODELOGI}

Penelitian ini dilakukan di Kabupaten Jembrana. Penelitian ini dilakukan dengan menyebarkan kueioner pada 10 akomodasi yaitu Puri Dajuma Beach Eco and Resort dan Kelapa Retreat Spa yang terletak di Kecamatan Pekutatan, Anara Surfing Camp dan Bali Tiger Hideaway yang terletak di Kecamatan Mendoyo, Hardy's Hotel dan Segara Mandala 
Hotel yang terletak di Kecamatan Jembrana, Jimbarwana Hotel dan Bali Sunset Hotel Jembrana yang terletak di Kecamatan Negara, The Arya Gilimanuk dan Taman Wana Resort Palasari yang terletak di Kecamatan Melaya untuk mengetahui pendapat wisatwan mengenai faktor-faktor yang mempengaruhi wisatawan dalam pemilihan akomodasi. Adapun indikator dalam penelitian ini terdiri dari harga, lokasi, kualitas peyananan, fasilitas, reputasi, promosi dan loyalti program. Teknik pengumpulan data menggunakan metode observasi, kuesioner, dokumentasi, studi kepustakaan. Teknik pengambilan sampel menggunakan accidental sampling dan penentuan jumlah sampel dihitung menggunakan rumus slovin dengan tingkat eror sebesar $10 \%$ dari jumlah populasi yang merupakan jumlah kunjungan wisatwan tahun 2018 berjumlah 260.431 orang. Berdasarkan perhitungan yang dilakukan menggunakan rumus slovin dengan jumlah populasi sebesar 260.431 orang dan tingkat eror sebear $10 \%$ maka didapat jumlah responden sebanyak 99,99 yang dibulatkan menjadi 100 orang responden. 100 responden tersebut nantinya akan dibagi menggunakan quota sampling, yaiu masing-masing 10 responden dari 10 akomodasi wisata yang telah ditentukan menjadi tempat dilakukannya penelitian ini..

Jawaban reponden dianalisis menggunakan analisis deskriptif kuantitatif dengan bantuan program SPSS versi 22. Adapun tahapan analisis data yaitu dengan Uji instrumen Penelitian yang terdiri dari Uji Validitas dan Uji Reliablilitas. Selanjutnya ada analisi Skala Likert dan Analisis Faktor. Analisi skala likert digunakan untuk menganalisis faktor-faktor yang mempengaruhi wisatawan dalam memilih akomodasi di Kabupaten Jembrana. Selanjutnya untuk menganalisis tanggapan wisatawan digunakan pengukuran ska la likert sehingga jawaban-jawaban wisatawan sesuai dengan variabel terhadap seluruh pertany aan yang diajukan dengan pemberian skor dengan nilai interval sebesar 0,80 . Poses analisis faktor terdiri dari beberapa tahapan yaitu membuat matrik korelasi yang terdiri dari Barlett's test of sphericity, Uji Kaiser Mayer Olkin (KMO), Uji Mesurement of Sampling. Tahap selanjutnya yaitu tahap menentukan jumlah faktor dengan eigen value $>1$, rotasi faktor dan interpretsi faktor.

\section{HASIL DAN PEMBAHASAN}

\subsection{Gambaran Umum Akomodasi di Kabupaten Jembrana}

Terdapat 117 unit akomodasi yang beroperasi dan tersebar di masing-masing kecamatan di Kabupaten Jembrana. Adapun dari 117 akomodasi yang ada di Kabupaten Jembrana ditentukan 10 akomodasi yang digunakan sebagai lokasi peneli tian penelituan ini, yaitu,

\section{Gambaran Umum Puri Dajuma Eco and Resort}

Puri Dajuma Eco and Resort merupakan salah satu akomodasi yang terletak di Kecamatan Pekutatan, Kabupaten Jembrana. Puri Dajuma Eco and Resort beralamat di jalan, yang dibangun di atas lahan sebesar kurang lebih 1,5 Ha. Terdapat beberapa jenis kamar yang tersedia yaitu deluxe cottage, pondok segara, silver suite, VIP cottage, dan bendega gold suite yang terbagi atas 35 kamar yang terdiri dari 18 cottages, 5 villa, dan 2 kamar suites.

Fasilitas kamar yang tersedia di Puri Dajuma Eco and Resort berupa 180 derajat sea view, free wifi, fasilitas anatar jemput bandara, layanan front office $24 \mathrm{jam}$, air conditioned room, ceiling fan, swimming pool, safety box dan lainnya. Harga kamar yang dipatok di Puri Dajuma Eco and Resort berkisar dari Rp 1.900.000,- sampai Rp 3.000.000,. Puri Dajuma Eco and Resort memiliki 1 buah restoran dengan nama Gourmet Paradise restaurant and bar. Restoran Gourmet Paradise ini menyediakan berbagai jenis Indonesian, Asian, American dan Vegetarian Food. Selain menyediakan akomodasi berupa 
kamar dan restoran, Puri Dajuma Eco and Resort juga menyediakan fasilitas lain berupa SPA and wellness service, open seminar room, dan wedding service.

\section{Kelapa Retreat and Spa}

Kelapa Retreat and Spa merupakan sebuah Luxurious Butique Hotel yang terdiri dari beberapa set bangunan villa yang dikelilingi oleh taman. Kelapa Retreat and Spa beralamat di jalan Ngurah Rai, Kecamatan Pekutatan, Kabupaten Jembrana. Terdapat beberapa jenis kamar yang tersedia di Kelapa Retreat and Spa yaitu Beach Pool Villa, Ocean Pool Villa, Garden Pool Villa, Kelapa Recidence, Beach Villa dan Ocean Villa. Adapun Fasilitas kamar yang tersedia berupa private swimming pool, beach facing terrance, AC dan ceiling fan, free internet access, tv with international channel dan outdoor bathroom.

Harga yang di patok di Kelapa Retreat and Spa berkisar dari harga Rp 1.900.000,sampai dengan Rp 4.250.000,- per malam. Terdapat satu restoran yang terdapat di Kelapa Retreat and Spa yang menyediakan menu breakfast, lunch dan dinner. Terdpat pula Samudra Spa yang menyediakan layanan spa dan paket yoga yang tersedia un tuk seluruh tamu yang menginap di Kelapa Retreat and Spa., dan wedding service sesuai dengan permintaan tamu.

\section{Anara Surfing Camp}

Anara Surfing camp merupakan akomodasi yang terletak di Desa Pulukan, Kecamatan Pekutatan. Lokasi akomodasi ini berada di tepi pantai pulukan sehingga memiliki pemandangan pantai yang langsung dapat dinikmati langsung dari kamar tamu. Anara surfing camp juga dilengkapi dengan fasilitas-fasilitas yang cocok untuk wisataw an surfing seperti penyewaan papan surfing dan juga fasilitas surfing course. Akomodasi ini juga menyewakan sepeda,sepeda motor dan fasilitas antar jemput bandara. Fasilitas ka mar yang dimiliki cukup terbatas dan standar dikarenakan akomodasi ini lebih menyasar wisatawan menengah kebawah dengan kisaran harga kamar rata-rata Rp 300.000,- per malam. Adapun fasilitas yang tersedia berupa free wifi, 24 hours receptionist service, free parking area dan breakfast.

\section{Bali Tiger Hideaway}

Bali Tiger Hideaway merupakan akomodasi yang memiliki design bangun an yang unik, berupa bangunan yang terbuat dari kayu dan bangunan yang lebih berbentuk tradisional. Berlokasi di Kecamatan Pekutatan, Kabupaten Jemrana, Bali Tiger Hide a way memberikan kesan berbeda bagi wisatawan yang menginap di Kabupaten Jembrana. Selain memiliki bangunan yang unik, Bali Tiger Hideaway merupakan budget hotel denga rate yang relative rendah, yaitu berkisar dari harga Rp 300.000,- sampai Rp 1.000.000,--

Jenis kamar yang tersedia di Bali Tiger Hideway terdiri dari tiga jenis yaitu Javanese Wooden Cottage, Bungalow Glamping Style, dan Bamboo Cottage. Terdapat beberapa fasilitas yang tersedia temasuk fasilitas untuk surfing dan juga yoga. Fasilitas kamar yang tersedia berupa breakfat, ceiling fan, free wifi dan free filtered drinking water.

\section{Hardys's Hotel}

Hardy's hotel merupakan hotel yang terletak di Kecamatan Jembrana te patny a di Jalan Ngurah Rai no 107, Pendem. Hardy's hotel merupakan city hotel yang lebih diperuntukan bagi wisatawan yang ingin menikmati suasana Kota Negara. Harga yang dipatok dengan harga Rp 100.000,-- sampai dengan Rp 500.000,- per mala mny a.Fasilitas yang tersedia berupa kamar yang dilengkapi dengan AC, dengan masing-masing kamar 
dilengkapi dengan teras,meja kerja dan kamar mandi pribadi. Selain itu terdapat pula fasilitas lain seperti shuttle service, dapur bersama yang dapat digunkan oleh tamu yang meninap.

\section{Segara Mandala Hotel}

Segara Mandala Hotel merupakan akomodasi yang terletak di Jalan Sudirman, Negara. Jaraknya kira-kira dapat ditempuh selama 30 menit dari Pelabuhan Gilimanuk. Walaupun berlokasi di pusat kota, namun suasana dari akomod asi ini dapat dikatakan tenang dan jauh dari keramaian. Terdapat berbagai macam fasilitas yang tersedia di Segara Mandala Hotel seperti kamar ber-AC dan ceiling fan, TV dan private bathroom. Harga yang diaptok untuk menginap di Segara Mandala Hotel dikategorikan terjangkau yaitu berisar dari harga Rp 50.000 sampai dengan Rp 250.000 per malamnya.

\section{Bali Sunset Hotel}

Bali Sunset Hotel merupakan hotel yang berlokasi di Jalan Pantai Rening, Negara. Akomodasi ini merupakan sebuah resort hotel yang lokasinya sekitar $10 \mathrm{~km}$ dari Pusat Kota Negara dengan dikelilingi oleh pemandandangan berupa pantai. Kamar-kamar y ang tersedia diposisikan di sekitar kolam renang dan dilengkapi pula dengan teras. Terdapat beberapa jenis aminities yang tersedia di Bali Sunset Hotel seperti kolam renang, bar/lounge, coffee shop, laundry service pool side bar, wifi, dan meeting room. Sedangkan pada kamar terdapat beberapa fasilita seperti flatscreen $T V$, mini bar, safety box, private bathroom dengan kamar yang ber-AC serta layanan room service. Harga yang dipatok dengan harga yang berkisar antara Rp 200.000,- hingga Rp 500.000 per malamnya.

\section{Hotel Jimbarwana}

Hotel Jimbarwana merupakan akomodasi yang terletak di tengah Kota Negara dimana hotel ini sangat cocok untuk wisatawan yang datang dengan tujuan berwisata maupun dengan tujuan lain seperti perjalannan bisnis. Jimbarwana Hotel menyediak an 46 kamar standart, 4 kamar suites, dan 1 presidential suites dengan beberapa fasilitas yang tersedia seperti Akses Wifi diseluruh area hotel, kamar dengan AC dan minibar, room service dan layanan front desk $2 \mathrm{jam}$. Selain itu tersedia pula fasilitas seperti meeting room dan kolam renang yang dapat diakses oleh tamu yang menginap. Harga kamar yang dipatok berkisar antara Rp 300.000,- sampai dengan Rp 1.000.000 per malam.

\section{The Arya Gilimanuk}

The Arya Gilimanuk merupakan guest house yang terletak di Kecamatan Melaya tepatnya di Jalan Gurami Gang 1, Gilimanuk. Akomodasi ini memiliki bangunan bergaya tradisional Bali dengan dikelilingi oleh taman. Kamar yang tersedia pada akomodasi ini dilengkapi dengan beberapa fasilitas seperti AC, free access internet, wardrobe, dan disertai pula dengan breakfast. Dengan harga yang berkisar antara Rp 200.000,- hingga Rp 500.000 ,- per malamnya wisatawan dapat menikmati tinggal di akomodasi y ang ny aman dan dekat dengan beberapa daya tarik wisata yang ada di Kabupaten Jembrana seperti Taman Nasional Bali Barat.

\section{Taman Wana Resort Palasari}

Taman Wana Resort merupakan akomodasi yang terletak di Kecamatan Melaya yaitu di Jalan Raya Taman Wana Palasari. Akomodasi ini dikelilingi oleh hutan sehingga memberikan suasana asri dan sejuk pada wisatawan yang menginap. Terdapat beberapa pilihan kamar yang tersedia di Taman Wana Resort Palasari yaitu Lagoon View Room, 
Deluxe Room with Balcony, dan Villa with Private Pool. Taman Wana Resort Palasari juga dilengkapi dengan beberapa fasilitas seperti kolam renang, taman yang mengelilingi seluruh area akomodasi dan beberapa pilihan makanan asia yang tersedia di Taman Wana Resort Restaurant. Harga yang dipatok berkisar dari Rp 500.000,- sampai dengan 4.000.000,- per malamnya.

\subsection{Uji Validitas}

Pada penelitian ini, hasil Uji Validitas yang diperoleh dari pengolahan data menggunakan program SPSS Versi 22 menunjukan bahwa koefisien korelasi dari 21 indikator dari 100 responden dengan $r_{\text {tabel }} 0,1966$ dinyatakan valid. Adapun $r_{\text {hitung }}$ dari masing-masing indikator dapat dilihat pada tabel berikut.

Tabel 5.Hasil Uji Validitas

\begin{tabular}{|c|c|c|c|c|}
\hline NO & Indikator & $\mathbf{r}_{\text {hitung }}$ & $\mathbf{r}_{\text {tabel }}$ & Keterangan \\
\hline 1 & $\mathrm{X} 1$ & 0,288 & 0,1966 & Valid \\
\hline 2 & $\mathrm{X} 2$ & 0,202 & 0,1966 & Valid \\
\hline 3 & X3 & 0,328 & 0,1966 & Valid \\
\hline 4 & $\mathrm{X} 4$ & 0,318 & 0,1966 & Valid \\
\hline 5 & $\mathrm{X} 5$ & 0,427 & 0,1966 & Valid \\
\hline 6 & X6 & 0,459 & 0,1966 & Valid \\
\hline 7 & $\mathrm{X} 7$ & 0,260 & 0,1966 & Valid \\
\hline 8 & $\mathrm{X} 8$ & 0,276 & 0,1966 & Valid \\
\hline 9 & $\mathrm{X} 9$ & 0,573 & 0,1966 & Valid \\
\hline 10 & $\mathrm{X} 10$ & 0,514 & 0,1966 & Valid \\
\hline 11 & $\mathrm{X} 11$ & 0,287 & 0,1966 & Valid \\
\hline 13 & $\mathrm{X} 12$ & 0,602 & 0,1966 & Valid \\
\hline 13 & $\mathrm{X} 13$ & 0,518 & 0,1966 & Valid \\
\hline 14 & $\mathrm{X} 14$ & 0,506 & 0,1966 & Valid \\
\hline 15 & $\mathrm{X} 15$ & 0,215 & 0,1966 & Valid \\
\hline 16 & $\mathrm{X} 16$ & 0,311 & 0,1966 & Valid \\
\hline 17 & $\mathrm{X} 17$ & 0,347 & 0,1966 & Valid \\
\hline 18 & $\mathrm{X} 18$ & 0,541 & 0,1966 & Valid \\
\hline 19 & X19 & 0,444 & 0,1966 & Valid \\
\hline 20 & $\mathrm{X} 20$ & 0,482 & 0,1966 & Valid \\
\hline 21 & $\mathrm{X} 21$ & 0,270 & 0,1966 & Valid \\
\hline
\end{tabular}

Sumber: Hasil Olah Data Kuesioner, 2019

Berdasarkan Tabel 5 di atas dapat dilihat bahwa dari 21 indikator yang dianalisis keseluruhan dari indikator memiliki nilai $r_{\text {hitung }}$ lebih besar dari 0,1966. Hal tersebut berarti 
bahwa dari 21 indikator yang diteliti, seluruh indikator dinyatakan valid dan layak untuk dilanjutkan ke tahap berikutnya

3.3 Uji Reliablilitas

Tabel 6 Hasil Uji Reabilitas Kuesioner

\section{Reliability Statistics}

Cronbach's Alpha

$\mathrm{N}$ of Items

.686

Sumber: Olah Data Kuesioner, 2019

Berdasarkan Tabel 7 di atas dapat dilihat bahwa hasil dari uji reabilitas menunjukan nilai 0,686 yang berarti bahwa data yang didapatkan dari kuesioner yang disebar telah memnuhi syarat reabilitas yaitu lebih dari 0,5 dan dapat dinyatakan reabel.

3.4 Faktor-faktor yang mempengaruhi wisatawan dalam pemilihan akomodasi di

Kabupaten Jembrana

Mengacu pada tahapan analisis faktor atas seleksi terhadap variabel pemilihan akomodasi di Kabupaten Jembrana, terdapat beberapa hal yang harus dilakukan, yaitu.

1) Hasil Uji Kaiser Mayer Olkin (KMO) dan Uji Barlett's Test of Sphericty

Tabel5.Ha sil Uji Kaiser Mayer Olkin (KMO) dan Bartlett's Test Sphericty

\section{KMO and Bartlett's Test}

Kaiser-Meyer-Olkin Measure of Sampling Adequacy.

Bartlett's Test of Sphericity

Approx. Chi-Square

Df

Sig.

.000

Sumber: Hasil Olah Data Kuesioner, 2019

Berdasarkan pada tabel 5 di atas, dapat dilihat bahwa hasil uji KMO dan Bartlett's Test pada penelitian ini mencapai angka 0,737 dan nilai signifikansi 0,000 . Hal tersebut menunjukan bahwa indikator-indikator yang diteliti layak untuk dilanjutkan ke tahapan berikutnya karena telah memenuhi syarat uji KMO yaitu >0,5 dan nilai signifikansi yang jauh dibawah 0,5. Sehingga dapat dilanjutkan pada analisis berikutnya.

\section{2) Hasil Uji Measure of Sampling (MSA)}

Uji Measure of Sampling merupakan uji yang dilakuakn etelah uji KMO dan Barlett's Test of Sphericty yang berguna untuk menentukan indikator-indikator yang lay ak untuk melakukan tahap uji selanjutnya. Inidkator-indikator yang dapat din y atakan lay ak untuk mengikuti uji selanjutnya yaitu indikator yang telah memnuhi syarat MSA lebih besar dari 0,5. Adapun hasil dari uji MSA yang dilakukan dapat dilihat pada tabel 6 dibawah ini. 
Tabel6. Ha sil Uji Mesure of Sampling Ta hap Pertama

\begin{tabular}{|c|c|c|}
\hline $\mathrm{NO}$ & Indikator & MSA \\
\hline 1 & $\begin{array}{l}\text { Pemilihan akomodasi karena harga akomodasi yang sesuai dengan fasilitas } \\
\text { akomodasi (X1) }\end{array}$ & 0,444 \\
\hline 2 & Pemilihan akomodasi karena pemberian potongan harga (X2) & 0,322 \\
\hline 3 & $\begin{array}{l}\text { Pemiliha n akomodasi karena adanya beberapa metode pembayaran (cash, credit/debit } \\
\text { card, etc.) (X3) }\end{array}$ & 0,628 \\
\hline 4 & Pemilihan akomodasi ka reana kemudahan akses menuju akomodasi (X4) & 0,563 \\
\hline 5 & Pemilihan akomodasi ka rena lokasi yang jauh dari keramaian (X5) & 0,719 \\
\hline 6 & Pemilihan akomodasi ka rena dekat dengan daya tarik wisa ta (X6) & 0,719 \\
\hline 7 & $\begin{array}{l}\text { Pemilihan akomodasi karena kemampuan staff dalam melakuan pelayanan } \\
\text { dengan tepat dan cepat }\left(\mathrm{X}_{7}\right)\end{array}$ & 0,463 \\
\hline 8 & $\begin{array}{l}\text { Pemilihan akomodasi karena kemampuan staff dalam membantu kebutuhan } \\
\text { konsumen (X8) }\end{array}$ & 0,475 \\
\hline 9 & Pemilihan akomodasi ka rena kemampuan staff melakukan komunikasi yang baik (X9) & 0,656 \\
\hline 10 & Pemilihan akomodasi ka rena kelengkapan fasilita s kamar (X10) & 0,661 \\
\hline 11 & Pemilihan Akomodasi karena kelengkapan fasilitas public area.(X11) & 0,428 \\
\hline 12 & Pemilihan akomodasi berdasarkan design bangunan akomodasi (X12) & 0,786 \\
\hline 13 & Pemilihan akomodasi berdasarkan referensi teman a tau kolega (X13) & 0,796 \\
\hline 14 & $\begin{array}{l}\text { Pemilihan akomodasi berdasarkan pandangan wisatawan terhadap akomodasi (review) } \\
\text { (X14) }\end{array}$ & 0,600 \\
\hline 15 & $\begin{array}{l}\text { Pemilihan akomodasi berdasarkan pandangan Masyarakat sekitar tentang a komodasi } \\
\text { (X15) }\end{array}$ & 0,511 \\
\hline 16 & $\begin{array}{l}\text { Pemilihan akomodasi ka rena adanya promosi yang dilakukan secara terus menerus } \\
\text { (X16 }\end{array}$ & 0,548 \\
\hline 17 & $\begin{array}{l}\text { Pemilihan akomodasi karena adanya promosi yang dilakukan secara unik dan } \\
\text { menarik (X17) }\end{array}$ & 0,475 \\
\hline 18 & Pemilihan akomodasi ka rena adanya promosi melalui internet. (X18) & 0,689 \\
\hline 19 & Pemilihan akomodasi ka rena adanya brand reward (X19) & 0,614 \\
\hline 20 & Pemilihan akomodasi karena adanya program membership (X20) & 0,638 \\
\hline 21 & Pemilihan akomodasi ka rena adanya pelayanan khusus untu Repeater Guest (X21) & 0,541 \\
\hline
\end{tabular}

Sumber: Olah Data Kuesioner, 2019

Pada tabel 6 di atas dapat dilihat bahwa setelah dilakukannya uji Measure of sampling terdapat 6 indikator yang memperoleh nilai kriteria MSA dibawah 0,5 sehingga indikator tersebut harus dikeluarkan dan dilakukan analisis tahap kedua. Adapun indikator-indikator yang belum memenuhi syarat pada uji MSA tahap 1 yaitu indikator pemilihan akomodasi karena harga akomodasi yang sesuai dengan fasilitas akomodasi (X1) dengan nilai MSA sebasar 0,044, pemilihan akomodasi karena pemberian potongan harga (X2) dengan nilai MSA sebesar 0,322, pemilihan akomodasi karena kemampuan staff dalam melakuan pelayanan dengan tepat dan cepat (X7) dengan nilai MSA sebasar 0,463, pemilihan akomodasi karena kemampuan staff dalam membantu kebutuhan konsumen (X8) dengan nilai MSA sebasar 0,475, pemilihan Akomodasi karena kelengkapan fasilitas public area.(X11) dengan nilai MSA sebasar 0,428, pemilihan akomodasi karena adanya promosi yang dilakukan secara unik dan menarik (X17) dengan nilai MSA sebasar 0,475. Adapun hasil uji Mesure Of Sampling tahap kedua dapat dilihat pada tabel berikut. 
Tabel 7.Hasil Uji Mesure of Sampling Tahap Kedua

\begin{tabular}{clc}
\hline NO & \multicolumn{1}{c}{ Indikator } & MSA \\
\hline 1 & $\begin{array}{l}\text { Pemilihan akomodasi karena adanya beberapa metodepembayaran (cash, credit/debitcard, } \\
\text { etc.)(X3) }\end{array}$ & 0,708 \\
2 & Pemilihan akomodasi ka reana kemudahan akses menuju akomodasi (X4) & 0,617 \\
3 & Pemilihan akomodasi karena lokasi yang jauh dari keramaian (X5) & 0,743 \\
4 & Pemilihan akomodasi karena dekat dengan daya tarik wisata (X6) & 0,767 \\
5 & Pemilihan akomodasi karena kemampuan staff melakukan komunikasi yang baik (X9) & 0,698 \\
6 & Pemilihan akomodasi karena kelengkapan fasilitas kamar(X10) & 0,734 \\
7 & Pemilihan akomodasi berdasarkan design bangunan akomodasi (X12) & 0,805 \\
8 & Pemilihan akomodasi berdasarkan referensiteman ataukolega (X13) & 0,874 \\
9 & Pemilihan akomodasi berdasarkan pandangan wisa tawan terhadapakomodasi (review) & 0,641 \\
& (X14) & $\mathbf{0 , 4 8 9}$ \\
10 & Pemilihan akomodasi berdasarkan pandangan Masyarakat sekitar tentang & \\
& akomodasi (X15) & 0,707 \\
11 & Pemilihan akomodasi ka rena adanya promosi yang dilakukan secara terus menerus (X16) \\
12 & Pemilihan akomodasi karena adanya promosi melalui internet. (X18) & 0,692 \\
13 & Pemilihan akomodasi karena adanya brand reward (X19) & 0,668 \\
14 & Pemilihan akomodasi karena adanya program membership (X20) & 0,677 \\
15 & Pemilihan akomodasi karena adanya pelayanan khusus untu Repeater Guest (X21) & 0,610 \\
\hline
\end{tabular}

Sumber: Olah Data Kuesioner, 2019

Jika dilihat pada tabel 7 di atas, hasil uji Measure of Sampling tahap kedua menunjukan bahwa masih terdapat satu indikator yang belum memenuhi kriteria MSA yaitu indikator pemilihan akomodasi berdasarkan pandangan Masyarakat sekitar tentang akomodasi (X15) dengan nilai MSA sebesar 0,489. Dengan demikian indikator tersebut harus dikeluarkan dan dilakukan uji Mesure of Sampling tahap ketiga. Adapun hasil dari uji MSA tahap ketiga dapat dilihat pada tabel berikut.

Tabel 8.Hasil Uji Mesure of Sampling Tahap 3

\begin{tabular}{clc}
\hline NO & \multicolumn{1}{c}{ Indikator } & MSA \\
\hline 1 & $\begin{array}{l}\text { Pemilihan akomodasi karena adanya beberapa metode pembayaran (cash, credit/debit } \\
\text { card, } \text { etc.) (X3) }\end{array}$ & 0,730 \\
2 & Pemilihan akomodasi kareana kemudahan akses menuju akomodasi (X4) & 0,617 \\
3 & Pemilihan akomodasi karena lokasi yang jauh dari keramaian(X5) & 0,751 \\
4 & Pemilihan akomodasi karena dekat dengan daya tarik wisata (X6) & 0,767 \\
5 & Pemilihan akomodasi karena kemampuan staff melakukan komunikasi yang baik (X9) & 0,692 \\
6 & Pemilihan akomodasi ka rena kelengkapan fasilita s kamar(X10) & 0,739 \\
7 & Pemilihan akomodasi berdasarkan design bangunan a komodasi(X12) & 0,810 \\
8 & Pemilihan akomodasi berdasarkan referensi teman a tau kolega (X13) & 0,882 \\
9 & Pemilihan akomodasi berdasarkan pandangan wisa tawan terhadapakomodasi (review) & 0,647 \\
& (X14) & \\
10 & Pemilihan akomodasi ka rena adanya promosi yang dila kukan secara terus menerus (X16) & 0,708 \\
11 & Pemilihan akomodasi karena adanya promosi melalui internet. (X18) & 0,715 \\
12 & Pemilihan akomodasi ka rena adanya brand reward (X19) & 0,684 \\
13 & Pemilihan akomodasi karena adanya program membership(X20) & 0,715 \\
14 & Pemilihan akomodasi karena adanya pelayanan khusus untu Repeater Guest (X21) & 0,598 \\
\hline
\end{tabular}

Sumber: Olah Data Kuesioner, 2019

Setelah dilakukan uji Mesure Of Samping tahap ketiga didapatkan 14 indikator yang telah memenihi kriteria MSA $>0,5$. Hal ini berarti 14 indikator di atas memiliki hubungan erat antar indikator dan setelah semua hasil memnuhi kriteria maka bisa dilanjutkan ke tahap berikutnya. 


\section{3) Hasil Ekstraksi Faktor}

Ekstraksi faktor dilakukan untuk menentukan berapa banyak faktor yang terbentuk mewakili variabel berdasarkan nilai eigen value pada setiap faktor yang muncul. Faktor-faktor yang dipilih adalah faktor yang memiliki nilai eigen value sama dengan atau lebih dari satu. Adapun dari hasil ekstraksi faktor yang telah dilakukan, didapatkan 4 faktor yang memiliki nilai Rigen Value lebih dari satu, yaitu pada tabel 9 berikut.

Tabel9.Faktor Dengan Eigen Value Diatas 1

\begin{tabular}{cccc}
\hline Faktor & Eigen Value & \% Of Variance & Cumulative \% \\
\hline $\mathbf{1}$ & 3.864 & 27.597 & 27.597 \\
$\mathbf{2}$ & 2.397 & 17.125 & 44.722 \\
$\mathbf{3}$ & 1.298 & 9.272 & 53.995 \\
$\mathbf{4}$ & 1.110 & 7.931 & 61.925 \\
\hline
\end{tabular}

Sumber: Olah Data Kuesioner, 2019

Berdasarkan tabel 9 terdapat 4 faktor yang terbentuk dari 14 indikator yang diteliti yang dianggap mempengaruhi wisatwan dalam pemilihan akomodasi di Kabupaten Jembrana. Berdasarkan besaran Eigen Value faktor yang paling dianggap meakili sekelompok indikator adalah faktor satu (1) dengan nilai Eigen Value paling besar yaitu 3,864 dengan Percent Of Varience sebesar $27,597 \%$. Pada faktor kedua yang terbantuk memiliki nilai eigen value sebesar 2,397 dengan nilai percent of varience sebesar $17,125 \%$. Selanjutnya pada faktor ketiga nilai eigen value sebesar 1,298 dan dengan nilai percent of varience sebesar 9,272\%. Pada faktir keempat yaitu memiliki nilai eigen value sebesar 1,110 dengan nilai percent of varience sebesar 7,931\%. Adapun nilai cumulative of varience sebesar $61,925 \%$ digunakan untuk menjelaskan empat faktor yang mempengaruhi wisatawan dalam pemilihan akomodasi di Kabupaten Jembrana.

\section{4) Hasil Rotasi Faktor}

Rotasi faktir digunakan untuk menyederhanakan matrik faktor yang memiliki struktur sulit untuk di interpretasikan. Rotasi faktor ini bertujuan untuk memperjelas posisi dari suatu indikator, akankah dimasukan pada faktir yang satu ataukah ke faktor yang lain. Adpun hasil dari rotasi faktor yang didapat dari analisis yang telah dilakukan dapat dilihat pada tabel 10 berikut.

Tabel 10.Hasil Rotasi Faktor Varimax

\begin{tabular}{|c|c|c|c|c|c|}
\hline No & Nama Variabel & $\begin{array}{l}\text { Nama } \\
\text { Faktor }\end{array}$ & $\begin{array}{l}\text { Eigen } \\
\text { Value }\end{array}$ & $\begin{array}{c}\text { Loading } \\
\text { Factor }\end{array}$ & $\begin{array}{c}\text { Percent } \\
\text { of } \\
\text { Variance }\end{array}$ \\
\hline 1 & $\begin{array}{l}\text { Pemilihan akomodasi ka rena kemampuan staff } \\
\text { melakukan komunikasi yang baik (X9) }\end{array}$ & & & 0,967 & \\
\hline 2 & $\begin{array}{l}\text { Pemilihan akomodasi karena kelengkapan } \\
\text { fasilita s kamar (X10) }\end{array}$ & & & 0,953 & \\
\hline 3 & $\begin{array}{l}\text { Pemilihan akomodasiberdasarkan design } \\
\text { bangunan akomodasi (X12) }\end{array}$ & $\begin{array}{l}\text { Kualitas } \\
\text { Pelayanan }\end{array}$ & 3.864 & 0,950 & 27.597 \\
\hline 4 & $\begin{array}{l}\text { Pemilihan akomodasi berdasarkan referensi } \\
\text { teman atau kolega (X13) }\end{array}$ & & & 0,793 & \\
\hline 1 & $\begin{array}{l}\text { Pemilihan akomodasiberdasarkan pandan gan } \\
\text { wisa ta wan terhadap a komodasi (review) (X14) }\end{array}$ & & & 0,809 & \\
\hline 2 & $\begin{array}{l}\text { Pemilihan akomodasikarena adanya promosi } \\
\text { yang dila kukan secara terus menerus (X16) }\end{array}$ & & & 0,674 & \\
\hline 3 & $\begin{array}{l}\text { Pemilihan akomodasi karena adanya promosi } \\
\text { melalui internet.(X18) }\end{array}$ & & & 0,667 & \\
\hline 4 & $\begin{array}{l}\text { Pemilihan akomodasikarena adanya brand } \\
\text { reward (X19) }\end{array}$ & & & 0,436 & \\
\hline
\end{tabular}




\begin{tabular}{|c|c|c|c|c|c|}
\hline 5 & $\begin{array}{l}\text { Pemilihan akomodasi karena adanya program } \\
\text { membership (X20) }\end{array}$ & Reputasi & 2.397 & 0,403 & 17.125 \\
\hline 6 & $\begin{array}{l}\text { Pemilihan akomodasi karena adanya pelayanan } \\
\text { khusus untu Repeater Guest (X21) }\end{array}$ & & & 0,422 & \\
\hline 1 & $\begin{array}{l}\text { Pemilihan akomodasi ka reana kemudahan } \\
\text { akses menuju akomodasi (X4) }\end{array}$ & & & 0,733 & \\
\hline 2 & $\begin{array}{l}\text { Pemilihan akomodasi karena lokasi yang jauh } \\
\text { dari keramaian (X5) }\end{array}$ & Lokasi & 1.298 & 0,677 & 9.272 \\
\hline 3 & $\begin{array}{l}\text { Pemilihan akomodasikarena dekat dengan } \\
\text { daya tarik wisata (X6) }\end{array}$ & & & 0,649 & \\
\hline 1 & $\begin{array}{l}\text { Pemilihan akomodasi karena adanya beberapa } \\
\text { metode pembayaran (cash, credit/debitcard, } \\
\text { etc.)(X3) }\end{array}$ & Harga & 1.110 & 0,686 & 7.931 \\
\hline
\end{tabular}

Sumber: Olah Data Kuesioner, 2019

Berdasrkan tabel 10 di atas, dapat dilihat bahwa didapatkan 4 faktor yang terbentuk dari 14 indikator. Adapun pada faktor pertama terdiri dari 4 indikator dengan percent of varience sebesar 27,597. Sedangkan faktor kedua terdiri dari 6 indikator dengan percent of varience sebesar 17,125. Faktor ketiga terdiri dari 3 indikator dengan percent of varience sebesar 9,272 dan faktor keempat terdiri dari 1 indikator dengan percent of varience sebesar 7,931.

\section{5) Interpretasi Faktor}

Interpretasi faktor merupakan pengelompokan indikator-indikator yang akan ditentukan menjadi sebuah faktor sesuai dengan loading factor yang didapat dan nantinya setiap faktor yang terbentuk akan diberikan namai sesuai dengan indikator pembentuknya. Adapun faktor-faktor yang terbentuk dari hasil analisis yang telah dilakukan yaitu sebagai berikut.

1) Faktor Kualitas Pelayanan

Faktor pertama yang terbentuk dari analisis yang telah dilakukan dan dianggap mempegaruhi wisatawan dalam pemilihan akomodasi di Kabupaten Jembrana yaitu faktor kualitas pelayanan. Faktor kualitas pelay anan memiliki nilai eigen value sebesar 3,864 dan percent of varience sebesar 27,597. Faktor kualitas ini terdiri dari 4 indikator yaitu:

a. Pemilihan akomodasi karena kemampuan staff melakukan komunikasi yang baik (X9),

b. Pemilihan akomodasi karena kelengkapan fasilitas kamar (X10),

c. Pemilihan akomodasi berdasarkan design bangunan akomodasi (X12),

d. Pemilihan akomodasi berdasarkan referensi teman atau kolega (X13).

Pada indikator Pemilihan akomodasi karena kemampuan staff melakukan komunikasi yang baik (X9) mendapat nilai factor loading sebesar 0,967 yang dapat diartikan bahwa semakin baik kemampuan staff dalam melukan komunikasi maka akan semakin mempengaruhi wisatawan dalam memilih akomodasi di Kabupaten Jembrana. Indikator pemilihan akomodasi karena kelengkapan fasilitas kamar (X10) memiliki nilai loading factor sebesar 0,953 dapat diartikan bahwa emakin lengkap fasilitas kamar y ang dimiliki akomodasi maka akan semakin mempengaruhi wisatawan dalam memilih akomodasi di Kabupaten Jembrana.

Pemilihan akomodasi berdasarkan design bangunan akomodasi (X12) memiliki nilai loading factor sebesar 0,950 yang dapat dinyatakan bahwa dalam pemilihan akomodasi berdasarkan pada design dari bangunan akomodasi yang ada di Kabupaten Jembrana. Pada indikator pemilihan akomodasi berdasarkan referensi teman atau kolega (X13). Memiliki loading factor sebesar 0,793 yang dapat diartikan bahwa semakin banyak referensi yang didapatkan oleh wisatawan dari teman atau kolega maka akan semakin berpengaruh pada pemilihan akomodasi di Kabupaten Jembrana.

2) Faktor Reputasi 
Faktor kedua yang terbentuk dari analisis yang dilakukan yaitu faktor reputasi dengan nilai eigen value sebesar 2,397 dan nilai percent of varience sebesar 17,125. Faktor ini terbentuk dari 6 indikator yaitu.

a. Pemilihan akomodasi berdasarkan pandangan wisatawan terhadap akomodasi (review) (X14),

b. Pemilihan akomodasi karena adanya promosi yang dilakukan secara terus menerus (X16),

c. Pemilihan akomodasi karena adanya promosi melalui internet. (X18),

d. Pemilihan akomodasi karena adanya brand reward (X19),

e. Pemilihan akomodasi karena adanya program membership (X20),

f. Pemilihan akomodasi karena adanya pelayanan khusus untu Repeater Guest (X21).

Indikator pemilihan akomodasi berdasarkan pandangan wisatawan terhadap akomodasi (review) (X14) memiliki nila loading factor sebesar 0,809 dimana pada indikator ini dapat dinyatakan bahwa semakin baik review wisatawan terhadap akomodasi maka akan semakin berpengaruh pula pada pemilihan akomodasi di Kabupaten Jembrana. Indikator Pemilihan akomodasi karena adanya promosi yang dilakukan secara terus menerus (X16) memiliki nilai loading factor sebesar 0,674 yanng dapat dinyatakan bahwa pemilihan akomodasi dipengaruhi oleh adanya promosi yang dilakukan secara terus menerus.

Selanjutnya pada indikator pemilihan akomodasi karena adanya promosi melalui internet. (X18) memiliki nilai loading factor sebesar 0,667 yang dapat dinyatakan bahwa adanya promosi melalui internet mempengaruhi wisatawan dalam pemilihan akomodasi di Kabupaten Jembrana. Indikator pemilihan akomodasi karena adanya brand reward (X19) memiliki nilai factor loading sebesar 0,436, dapat dinyatakan bahwa semkin banyak adanya brand reward yang diberikan oleh akomodasi maka akan semakin mempengaruhi wisatawan dalam pemilihan akomodasi di Kabupaten Jembrana.

Indikator pemilihan akomodasi karena adanya program membership (X20) memiliki nilai loading factor sebesar 0,403 yang menyatakan bahwa semakin banyak adanya program membership pada akomodasi akan semakin mempengaruhi wisatawan dalam memilih akomodasi di Kabupaten Jembrana. Indikator pemilihan akomodasi karena adanya pelayanan khusus untuk Repeater Guest (X21) dengan nilai loading factor sebesar 0,422 menyatakan bahwa dengan adanya pelayanan khusus untuk repeater guest maka akan semakin mempengaruhi wisatawan dalam memilih akomodasi di Kabupaten Jembrana.

\section{3) Faktor Lokasi}

Faktor ketiga yang terbentuk dari analisis yang telah dilakukan yaitu faktor lokasi. Faktor ini terdiri atas 3 indikator dengan nilai eigen value sebesar 1,298 dan nilai percent of varience sebesar 9,272. Adapun indikator pada faktor place terdiri dari:

a. Pemilihan akomodasi kareana kemudahan akses menuju akomodasi (X4),

b. Pemilihan akomodasi karena lokasi yang jauh dari keramaian (X5),

c. Pemilihan akomodasi karena dekat dengan daya tarik wisata (X6).

Indikator pemilihan akomodasi kareana kemudahan akses menuju akomodasi (X4) memiliki nilai loading factor sebesar 0,733 dan pada indikator ini dapat dinyatakan bahwa semakin mudah akses menuju akomodasi maka akan semakin mempengaruhi wisatwan dalam pemilihan akomodasi di Kabupaten Jembrana. Pada indikator pemilihan akomodasi karena lokasi yang jauh dari keramaian (X5) memiliki nilai loading factor sebesar 0,677 dan pada indikator ini dapat dinyatakan bahwa semakin jauh letak akomodasi dari keramaian maka akan semakin mempengaruhi wisatawan dalam pemilihan akomodasi di Kabupaten Jembrana. Selanjutnya pada indikator pemilihan akomodasi karena dekat dengan daya tarik wisata (X6) memiliki nilai factor loading sebesar 0,649 dan dapat dinyatakan bahwa semakin dekat akomodasi dengan daya tarik wisata maka akan semakin mempengaruhi wisatawan dalam memilih akomodasi di Kabupaten Jembrana. 


\section{4) Faktor Harga}

Faktor keempat yang terbentuk dari analisis yang telah dilakukan yaitu faktor harga. Faktor ini terbentuk dari 1 indkator dengan nilai eigen value sebesar 1,110 dan percent of varience sebesar 7,931. Indikator yang membentuk faktor ini yaitu pemilihan akomodasi karena adanya beberapa metode pembayaran (cash, credit/debit card, etc.) (X3) dengan nilai loading factor sebesar 0,686. Pada indikator ini dapat dinyatakan bahwa pemilihan akomodasi oleh wisatawan di Kabupaten Jembrana dipengaruhi oleh adanya beberapa metode pembayaran yang tersedia. Dengan adanya semakin banyak metode pembayaran yang tersedia maka akan semakin mempengaruhi wisatawan dalam memilih akomodasi di Kabupaten Jembrana.

\subsection{Faktor yang dominan mempengaruhi wisatawan dalam pemilihan akomodasi di \\ Kabupaten Jembrana}

Berdasarkan analisis faktor yang telah dilakukan, maka diperoleh 4 faktor yang terbentuk dari 14 indikator. Faktor tersebut terdiri dari faktor kualitas pelayanan, faktor reputasi, faktor lokasi dan faktor harga. Untuk mengetahui faktor yang paling dominan mempengaruhi wisatawan dalam pemilihan akomodasi di Kabupaten Jembrana dapat dilihat pada nilai tertinggi eigen value dari faktor yang terbentuk. Pada faktor kualitas pelayanan memiliki nilai eigen value sebesar 3,864, faktor reputasi memiliki nilai eigen value sebesar 2,397, faktor lokasi memiliki nilai eigen value sebesar 1,298 dan faktor harga memiliki nilai eigen value sebesar 1,110. Dengan demikian, faktor yang dapat dikatakan sebagai faktor yang paling dominan mempengaruhi wisatwan dalam pemilihan akomodasi di Kabupaten Jembrana yaitu faktor kualitas pelayanan dengan nilai eigen value sebesar 3,864 dengan percent of variance sebesar 27,597\%.

Faktor kualitas pelayanan terbentuk atas 4 indikator yang mempengaruhi wisatawan dalam pemilihan akomodasi di Kabupaten Jembrana. Adapun 4 indikator tersebut terdiri dari Pemilihan akomodasi karena kemampuan staff melakukan komunikasi yang baik, pemilihan akomodasi karena kelengkapan fasilitas kamar, pemilihan akomodasi berdasarkan design bangunan akomodasi, pemilihan akomodasi berdasarkan referensi teman atau kolega. Faktor kualitas pelayanan merupakan faktor yang penting dalam proses pemasaran. Dalam proses pemasaran khususnya pemasaran jasa, produk yang ditawarkan biasanya berbeda yaitu berupa pelayanan.

Pemilihan akomodasi di Kabupaten Jembrana oleh wisatwan didasarkan atas beberapa hal meliputi kemampuan staff dalam berkomunikasi. Dalam hal ini kemampuan staff dalam berkomunikasi yang dimaksud adalah kemampuan dalam menggunakan bahasa inggris dan kemampuan untuk mengerti kebutuhan wisatawan yang meninap di Akomodasi di Kabupaten Jembarna. Pada akomodasi yang tesedia di Kabupaten Jembrana, staff yang ada pada akomodasi sudah mampu berkomunikasi dengan baik khususnya dalam menggunakan bahasa inggris. Selanjutnya pemilihan berdasarkan kelengkapan fasilitas kamar dimana fasilitas kamar yang tersedia pada akomodasi di Kabupaten Jembrana berupa kamar yang mengarah langsung ke pantai, tersedia pula pilihan kamar dengan menggunakan AC maupun fan dan fasilitas free acces wifi yang dipilih sebagai alternative menginap oleh wisatwan yang berkunjung ke Kabupaten Jembrana.

Pemilihan akomodasi oleh wisatawan juga berdasarkan design banngunan dari akomodasi, dimana desain bangunan dari akomodasi di Kabupaten Jembrana memiliki perbedaan tergantung pada lokasinya. Misalnya akomodasi yang berlokasi di Kecamatan Pekutatan seperti Puri Dajuma Eco Beach and Resort dan Kelapa Retreat and Spa memiliki desain bangunan modern dan mengangkat kemewahan. Bangunan dirancang agar dapat mengakses langsung daerah pantai yang ada di daerah akomodasi yang ada di Kecamatan Pekutatan. Sama halnya dengan akomodasi di Kecamatan Pekutatan, akomodasi yang ada di Kecamatan Mendoyo lebih menonjolkan pantai sebagai daya tarik utama yang dimiliki, hanya saja desain bangunan dari akomodasi yang ada di Kecamatan Mendoyo contohnya Anara Surfing Camp dan Bali Tiger Hideaway memiliki desain bangunan yang sederhana. Desain bangunan yang dimiliki disesuaikan dengan pangsa pasar dari akomodasi wisata tersebut yaitu wisatwan yang datang dengan tujuan surfing.

Pada akomodasi yang ada di Kecamatan Negara dan Jembrana memiliki kesamaan yaitu lebih memperlihatkan desain bangunan yang modern yang disesuaikan dengan situasi kota. Bangunan yang ada berupa bangunan bertingkat dengan desain minimalis seperti pada Hardy's 
Hotel, Segara Mandala Hotel, dan Jimbarwana Hotel. Sedangkan pada akomodasi yang ada di Kecamatan melaya misalnya The The Arya Guest House Gilimanuk dan Taman Wana Resort Palasari memiliki desain bangunan yang lebih mengarah pada bangunan tradisional bali. Pada bangunan tersebut terdapat ornamen-ornamen yang menunjukan bangunan bali seperti ukiranukiran bali pada bangunannya. Selanjutnya pemilihan akomodasi berdasarkan pada referensi teman atau kolega mempengaruhi wisatawan dalam memilih akomodasi di Kabupaten Jembrana, dimana dari penelitian yang telah dilakukan, sebagian besar wisatawan yang menginap pada akomodasi di Kabupaten Jembrana merupakan repeater guest dan menyatakan bahwa pemilihan akomodasi dikarenakan adanya remomendasi dari teman atau kolega.

\section{KESIMPULAN}

Berdasarkan hasil analisis dan pembahasan yang telah dipaparkan pada bab sebelumnya, maka dapat ditarik beberapa simpulan, yaitu terdapat 4 faktor yang terbentuk dari 14 indikator yang mempengaruhi wisatawan dalam pemilihan akomodasi di Kabupaten Jembrana. Faktor pertama adalah faktor kualitas pelayanan yang terdiri dari 4 indikator yaitu pemilihan akomodasi karena kemampuan staff melakukan komunikasi yang baik, pemilihan akomodasi karena kelengkapan fasilitas kamar, pemilihan akomodasi berdasarkan design bangunan akomodasi, pemilihan akomodasi berdasarkan referensi teman atau kolega. Faktor kedua yaitu faktor reputasi yang terdiri dari 6 indikator yaitu Pemilihan akomodasi berdasarkan pandangan wisatawan terhadap akomodasi (review), Pemilihan akomodasi karena adanya promosi yang dilakukan secara terus menerus, Pemilihan akomodasi karena adanya promosi melalui internet, pemilihan akomodasi karena adanya brand reward, pemilihan akomodasi karena adanya program membership, Pemilihan akomodasi karena adanya pelayanan khusus untu Repeater Guest. Faktor Ketiga yang terbentuk adalah faktor lokasi yang terdiri atas 3 indikator yaitu pemilihan akomodasi kareana kemudahan akses menuju akomodasi, pemilihan akomodasi karena lokasi yang jauh dari keramaian, pemilihan akomodasi karena dekat dengan daya tarik wisata. Dan faktor keempat yang terbentuk adalah faktor harga yang terbentuk dari 1 indikator yaitu pemilihan akomodasi karena adanya beberapa metode pembayaran (cash, credit/debit card, etc.).

Berdasarkan penelitian yang telah dilakukan, faktor yang paling dominan mempengaruhi wisatawan dalam pemilihan akomodasi di Kabupaten Jembrana yaitu faktor kualitas pelayanan dengan nilai eigen value sebesar 3,864 dengan percent of variance sebesar 27,597\%. Faktor kualitis pelaynan terbentuk atas 4 indikator yang mempengaruhi wisatawan dalam pemilihan akomodasi di Kabupaten Jembrana. Adapun 4 indikator tersebut terdiri dari Pemilihan akomodasi karena kemampuan staff melakukan komunikasi yang baik, pemilihan akomodasi karena kelengkapan fasilitas kamar, pemilihan akomodasi berdasarkan design bangunan akomodasi, pemilihan akomodasi berdasarkan referensi teman atau kolega. Faktor produk merupakan faktor yang penting dalam proses pemasaran. Dalam proses pemasaran khususnya pemasaran jasa, produk yang ditawarkan biasanya berbeda yaitu berupa pelayanan.

\section{Ucapan terima kasih}

Penulis mngucapkan terimakasih kepada Dinas Pariwisata Kabupaten Jembrana dan pengelola akomodasi wisata di Kabupaten Jembrana yang telah berkenan memberikan ijin ke pada penulis untuk melakukan penelitian di lokasi yang bersangkutan. Kepada wisatawan yang telah berkenan memberikan tanggapannya terkait penelitian. Kepada dosen pembimbing yang telah senantiasa membimbing dan mengarahkan penulis dalam menyelesaikan laporan akhir ini. Kepada seluruh dosen Program Studi Diploma IV Pariwisata yang telah memberikan pelayanan dan dukungan yang baik kepada penulis. Kepada teman-teman Program Studi Diploma IV Pariwisata 2015 yang telah memberikan semangat serta dukungan kepada penulis untuk menyelesaikan laporan akhir program ini. 


\section{DAFTAR PUSTAKA}

Abdurachman, Ujianto. 2004. Faktor-Faktor yang Menimbulkan kecendrungan Minat Beli Konsumen Sarung, Jurnal Manajemen \& Kewirausahaan. Vol. 6, No. 1.

Agustini, Ni Wayan Siska. 2018. Preferensi Wisatawan Terhadap Pemilihan Akomodasi di Kabupaten Bangli. JKH Vol. 2 No.1. April 2018. Denpasar: Universitas Udayana

Anonim. 2004. Pengertian pengunjung, World Tourism Organization

Anonim. 2018. Jumlah Kunjungan Wisatawan Mancanegara dan Wisataw an Nusantara ke Bali. Denpasar: Dinas Pariwisata Provinsi Bali

Anonim. Data Jumlah Kunjungan Wisatawan Dinas Pariwisata Provinsi Bali Tahun 2019

Arikunto, S. 2006. Metode Penelitian Kualitatif. Jakarta: Bumi Aksara

Azwar. Azrul dan Prihartono, J. 1986. Metodelogi Penelitian. Jakarta: Salemba 4

Badan Pusat Statistik Kabupaten Jembrana, 2018. Direktori Kabupaten Jembrana. Jembrana: BPS Kabupaten Jembrana

Barsky.J, 1992. Customer Satisfaction in the Hotel Industry: Measurement and meaning, cornell H.R.A, Quaeterly, Vol.7.pp.20-41

Budi, Agung Permana. 2013. Manajemen Marketing Perhotelan. Yogyakarta: CV Andi Offset

Charles W. Lamb, Joseph F. Hair, Carl McDaniel. 2001. Pemasaran, Edisi pertama. Jakarta: Salemba Empat

Dinas Pariwisata Kabupaten Jembrana. 2018, Data Jumlah Akomodasi di Kabupaten Jembrana. Jembrana: Dinas Pariwisata Kabupaten Jembrana

Dymyati, Aan Surachlan. 1989.Pengetahuan Dasar Perhotelan. PT: Daviragnan

Hanink, D, M. 1997. Principles and Application of Economic Geography. New Jersey: John Wiley \& Sons, Inc

Hasan, Ali. 2013. Marketing dan Kasus-Kasus Pilihan. Yogyakarta. CAPS (Center For Academic Publishing Service)

Heizer, J. dan Render, B. 2006. Operation Management.Edisi Terjemahan. Jakarta: Salemba Empat

Ismayanti. 2010. Pengantar Pariwisata. PT. Gramedia Widiasarana Indonesia, Jakarta.

Komar, Ricard. 2006. Hotel Manajemen (Manajemen Perhotelan). Jakarta : Gramedia Widia Sarana Indonesia

Kotler, Philip and Gary M. 2008. Amstrong principles of Marketing The 12thedition 2008. US: Pearson education

Kotler, Philip dan Keller. 2007. Manajemen Pemasaran, Jilid I, Edisi Kedua belas. PT. Indeks, Jakarta

Kotler, Philip dan Kevin Lane. 2009. Manajemen Pemasaran edisi baru. Jakarta: Erlangga

Kotler, Philip. 2006. Manajemen Pemasaran, Edisi Pertama. Indonesia: PT. Indeks Kelompok Gramedia

Lupiyadi, Rambat . 2014 . Manajemen Pemasaran Jasa. Jakarta:Salemba Empat

Parasuraman. A, V.A.ZEithml dan L.L.Berry.1998. Multiple item Scale for Measuring Consumer Perception of Service Quality, Hal 64, Journal Of Retailing

Pitana, I Gede dan I Ketut Surya Diarta. 2009. Pengantar Ilmu Pariwisata. Jakarta:Andi Publisher

Putra, Bagus Septiantara. 2018. Faktor-faktor yang mempengaruhi keputusan wisatan berbelanja souvenir ke Jogger Pabrik Kata-Kata Kuta. Denpasar: Universitas Udayana

Simamora, Henry. 2007. Manajemen Sumber Daya Manusia. Yogyakarta: STIE YKPN 
Soekadijo, R. G. (2000). Anatomi Pariwisata. Jakarta: Penerbit PT Gramedia Pustaka Utama

Sopiah dan Sangadji, E.M.,. 2013. Prilaku Konsumen: Pendekatan Praktis Disertai:Himpunan Jurnal Penelitian. Yogyakarta: Penerbit Andi

Sugiyono. 2005. Memahami Penelitian Kualitatif. Bandung: CV. Alfabeta

---------. 2009. Metode Penelitian Administratif. Bandung: Alfabeta

---------. 2013. Metode Penelitian Pendidikan Pendekatan Kuantitatif, Kualitatif, dan $R \& D$. Bandung: Alfabeta

---------2012. Metode Penelitian Kuantitatif dan R\&D. Bandung : Alfabeta 2016. Metode Penelitian Kuantitatif dan R\&D. Bandung: Alfabeta

Sulastiyono, Agus. 2006. Manajemen Penyelenggaraan Hotel. Bandung; Alfabeta

Sumarwan, Ujang. 2003. Perilaku Konsumen, Teori Dan Penerapannya Dalam Pemasaran. Ghalia Indonesia. Jakarta

Sumarwan, Ujang. 2012. Riset Pemasaran dan Konsumen

Sunyoto, Danang. 2012. Manajemen Sumber Daya Manusia. Jakarta: PT Buku Seru

Susanto, Singgih. 2018. Statistik Multivariat dengan SPSS.Jakarta : Pt Elex Media Komputindo

Susilowati, M.H. Dewi, dkk. "Model Penggunaan Ruang Kawasan Wisata Kuta - Bali”, PPGT - Departemen Geografi Fakultas Matematika dan Ilmu Pengetahuan Alam Universitas Indonesia

Suwena, I Ketut dan I Gusti Ngurah Widyatmaja. 2010. Pengetahuan Dasar ilmu Pariwisata. Denpasar: Udayana University Press

Tjiptono, Fandy. 2006. Strategi Pemasaran, Edisi 1. Yogyakarta: Penerbit Andy Tjiptono, Fandy. 2008. Strategi Pemasaran, Edisi 3. Yogyakarta: Penerbit Andy

Tjiptono, Fandy. 2014, Pemasaran Jasa - Prinsip, Penerapan, dan Penelitian, Yogyakarta: Andi Offset

Umar, Husein. 2003. Metodelogi Penelitian: Aplikasi dalam Pemasaran. Jakarta: Gramedia Pustaka Utama

Utama, I Gusti Bagus Rai. 2016. Metedologi Penelitian Pariwisata dan Hospitality. Bali : Pustaka Larasan

World Tourism Organization. 2004.Pengertian pengunjung. UN-WTO

Yoeti, Oka A. 2001. Pemasaran Pariwisata. Bandung: Angkasa

2004. Strategi Pemasaran Hotel. Jakarta : Gramedia Pustaka Utama 